\title{
Factors Affecting Demand for Compost: A Case Study in Kurunegala
}

\author{
S. T. Rashmika and J. C. Edirisinghe ${ }^{\#}$ \\ Department of Agribusiness Management, \\ Faculty of Agriculture and Plantation Management, \\ Wayamba University of Sri Lanka, Makandura, Gonawila (NWP). \\ \#Corresponding Author: \\ E-mail: jagathed@yahoo.com
}

\begin{abstract}
Composting, as widely believed, is a solution to the ever-increasing solid waste management problem around the world. Most countries convert urban solid waste into compost because of its expected use in productive agriculture. With rising urban waste around the country, the production of compost will also rise in times to come. However, the success of management of solid waste through composting entirely depend on the usage of compost by the farming community, because without demand for such compost, it is not possible to dispose the production. Therefore, this research attempt to analyze the demand for compost by collecting primary data from 100 farmers around Kurunegala area. The data collection method in this study was face-to-face interviews using a pre-tested questionnaire. Several focus groups $(N=3)$ aided the development of questions in the questionnaire. A Multiple Linear Regression was estimated by associating six factors to the amount of compost used by farmers in the area. Regression results shows that income, land extent, sand content, price, and the cultivation type have significant impact on demand. While all other variables showed a positive effect on demand, price and sand content (low quality) showed a negative impact. Results highlighted that for composting to be a viable solution in managing urban solid wastes, a proper marketing campaign is in order by using the four Ps of marketing, the Product, Price, Place, and the Promotion, in a 'right' mix.
\end{abstract}

KEYWORDS: Compost, Municipal waste, Waste management

\section{Introduction}

Households, institutions and the public create municipal waste. Disposing municipal waste has become a major problem in many developing countries because of the increase in population and the rapid urbanization (Palatnik et al., 2005). The current practice of disposal of such wastes is dumping in less populated areas away from main town centers and densely populated areas or using the waste for land filling (Burntley, 2007). Such dumping or land filling creates its own problems. For 
instance, waste particles may seep into the ground water system and create water pollution, which lead to very serious health problems (Hasan, 2009). Additionally soil pollution and spreading of diseases occur. Production of large amounts of Methane results in bad smell around these dumping sites (Ahmed and Zurbrugg, 2002).

In the Sri Lankan context, Urban Councils collect waste and dump without proper management in selected dumping sites around the country. Being a tropical country, Sri Lanka finds itself in difficulties in burning Municipal Solid Waste (MSW), leading to creation of huge waste mountains in dumping sites. This has created an unpleasant environment with bad smell, mosquitoes and other health problems near these dumping sites creating widespread opposition to such dumping by the general public. For example, "In December 2012 the Meethotamulla Rahula Vidyalaya was closed as the garbage dump was very close to the school and it was very difficult for the school to function" (Walpola, 2016).

To avoid the problem created by MSW, many countries along with Sri Lanka, convert such waste to compost, which is one of the uses of those wastes by urban councils and other private organizations (Sharholy et al., 2008). "Compost is the product of organic matter digested by organisms that is used to improve soil structure and to provide nutrients like Nitrogen, Phosphorous, Potassium and it contains a range of beneficial materials" (Rouse, 2008). "The end markets of the compost can be agricultural, commercial and residential, erosion control and landscaping" and may act as pollution preventing matter (Alzaydi et al., 2013; Cole et al., 1995).

In Sri Lanka as well as many other developing countries, one of the problems faced by compost production produced using MSW is the lack of a market for the compost. Therefore, large amounts of end product of compost is gathered in the production plant without selling making them even unable to cover up their initial investment (Guerrero et al., 2013). Therefore, the main objective of this study is to analyze the nature of demand for compost to provide guidelines to improve its sales.

\section{METHODOLOGY}

\section{Theoretical Framework}

To relate the compost demand to the set of covariates believed to impact usage of compost, this study assumed a linear demand function as below.

$Y=\beta_{0}+\beta_{1} I+\beta_{2} L E+\beta_{3} S C+\beta_{4} P+\beta_{5} P a+\beta_{6}$ OFC $+\epsilon$

Where,

$Y \quad=$ Quantity/month

$I \quad=$ Income/month 


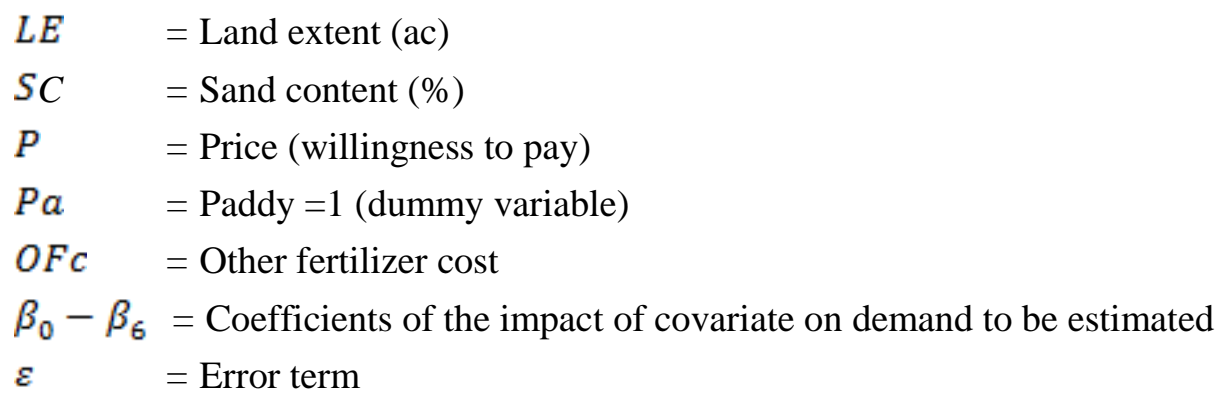

Quantity $(\mathrm{kg})$ is the total usage on the entire land cultivated by each farmer. Income which was generated from the cultivating the crop using compost in Rupees was used as income of the farmers. Land extent (ac) was the cultivated land area of the crop by solely using compost. Sand content is the percentage of sand in the compost as indicated by the respondent. This is included as a proxy variable to detect quality of the compost used.

Price was the willingness to pay, reported by farmers in rupees per $1 \mathrm{~kg}$ of compost. A dummy variable for paddy cultivation was also included where the variable is equal to 1 if the farmer cultivate paddy. Other fertilizer cost $(\mathrm{Rs} / \mathrm{kg})$ is the unit cost of other fertilizer used in their lands, which may be a substitute for compost.

\section{Data Collection}

Because the interest of the research is to understand the demand for compost in order to address the solid waste management problem, data collection was around one of the major composting unit using urban solid waste in Kurunegala (Sundarapola plant). This is one of the 115 such compost production plants in Sri Lanka.

The primary data were from farmers in 12 Grama Niladari Division (GND) which are around the Sundarapola compost production plant in Kurunegala to capture the immediate market for compost (Folefack et al., 2012). Based on the population in each GND, farmers were randomly selected from each Grama Niladari Division. A questionnaire based survey was used with face to face interviews for data collection.

A pilot survey conducted prior to the real survey with a representative sample of 10 respondents validated the questionnaire. The questionnaire was developed using information generated from focus groups $(\mathrm{N}=3)$ conducted. The survey questionnaire consisted of questions to collect information on farmer's income, cropping land extent, compost usage and other fertilizer usage. Finally information were gathered from 100 respondents was used in the analysis. 


\section{Results and Discussion}

\section{Descriptive Statistics of the Sample}

Description of respondents in the sample are in Table 1. There are two clear groups of farmers based on their income level; more than and less than Rs. 8000 per month. The majority were in the category of income of less than Rs.8000 (66\%) while $34 \%$ was under the more than 8000 Rupees. Amongst the farming community in the area, $31 \%$ is involved in paddy cultivation only while $69 \%$ of the farmers grow vegetables, fruits, and mix crops.

Table 1. Socio demographic characters of respondents

\begin{tabular}{lc}
\hline \multicolumn{1}{c}{ Parameter } & Percentage (\%) \\
\hline Income & 34 \\
More than 8000 & 66 \\
Less than 8000 & \\
Crop type & 31 \\
Paddy & 69 \\
Other & \\
Obtaining type & 75 \\
Self-production only & 14 \\
Purchase only & 11 \\
Both & \\
Land extent & 33 \\
More than 1ac & 67 \\
Less than 1 ac & \\
Purchasing type & 84 \\
Cash basis & 16 \\
Credit basis & \\
Problems when usage & 47 \\
Occur & 53 \\
Doesn't occur &
\end{tabular}

Most of the farmers (75\%) produced compost by their own. Paddy farmers can produce compost very easily by paddy straw after harvesting paddy. Others produced using leaves, animal manure, grasses, food wastage, and banana stem. Self-production process is a minimal cost process and leads to productions in larger amounts in three to four months. Most of the farmers used this method due to its cost effectiveness and because they believed that they can obtain, high quality, secure compost for their cultivation.

About fourteen percent of farmers purchased compost for their usage. They purchased in 5,15 and $25 \mathrm{~kg}$ bags according to their consumption. It's useful for quick usage, when there is not enough time for self-production, no space available 
and no materials available. Eleven percent of the farmers used both types of compost.

Figure 1 shows the distribution of cultivated land using compost among the 12 GN Divisions selected for the study. Sixty seven percent of the cultivated land areas are less than 1ac, which mainly consists of cultivations other than paddy. This may be due to lack of space because higher population and urbanization. Thirty three percent of the land extent is more than 1ac, which mainly consists of paddy lands but a few are vegetable cultivations.

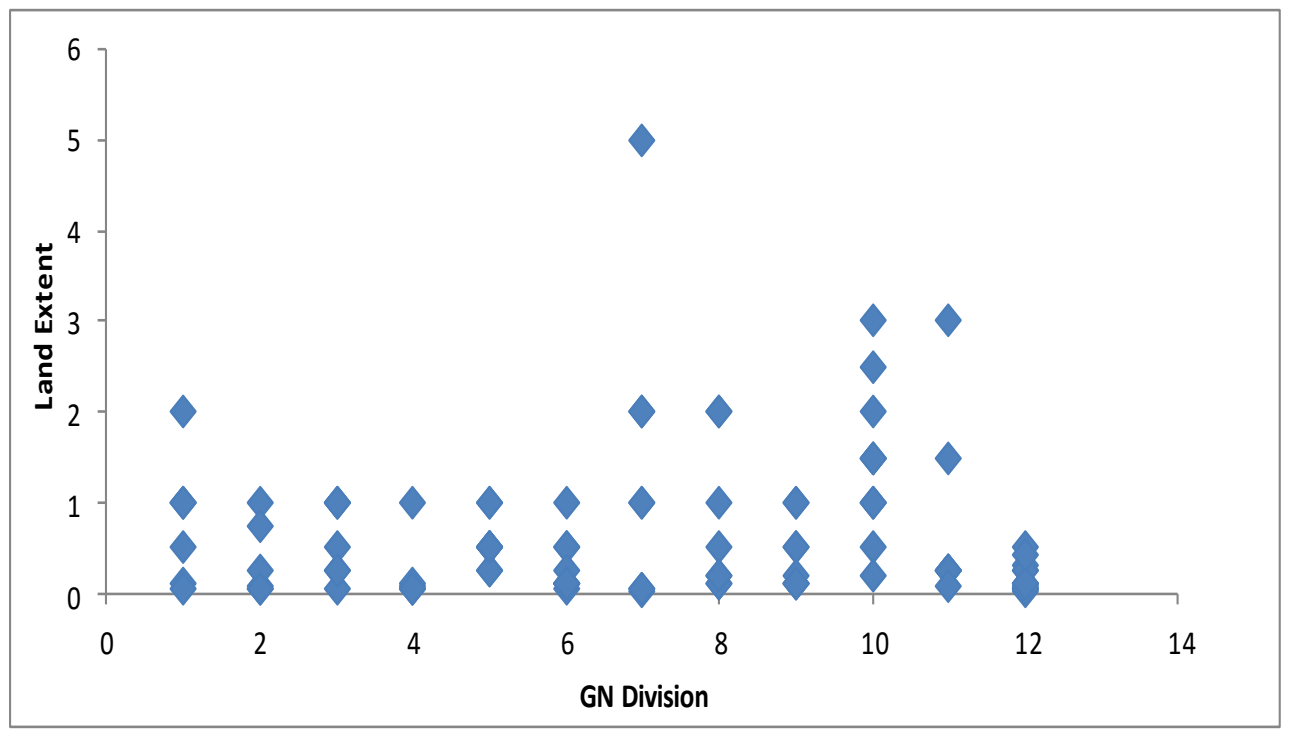

Figure 1. Cultivating land extent using compost. 1- Kurunegala North East, 2Kalahogedara, 3- Mavidalupotha, 4- Kurunegala West, 5- Bamunugedara, 6- Wewagedara, 7- Aswedduma, 8- Dematagahapelessa, 9- Udabadalawa, 10- Thiththawella, 11Kawdawatta, 12- Udadigana

Most of the respondents tend to purchase unique compost product and most of the companies produced it and market with a good and reliable output. So, farmers who are loyal to such brand names and only consider that product for purchased. Because they are sure that product will give the best results and won't cause any harmful effects for the cultivation.

The majority of the respondents (84\%) are more likely to purchase compost on cash basis while some respondents that cultivate in large amounts wish to purchase on credit basis (16\%), Due to the large quantity of compost requires and farmer cannot tolerate such huge cost that spend for it .

Figure 2, show that there's a seasonality of usage of compost. It indicates the number of respondents who stated the months in which their usage is highest. 


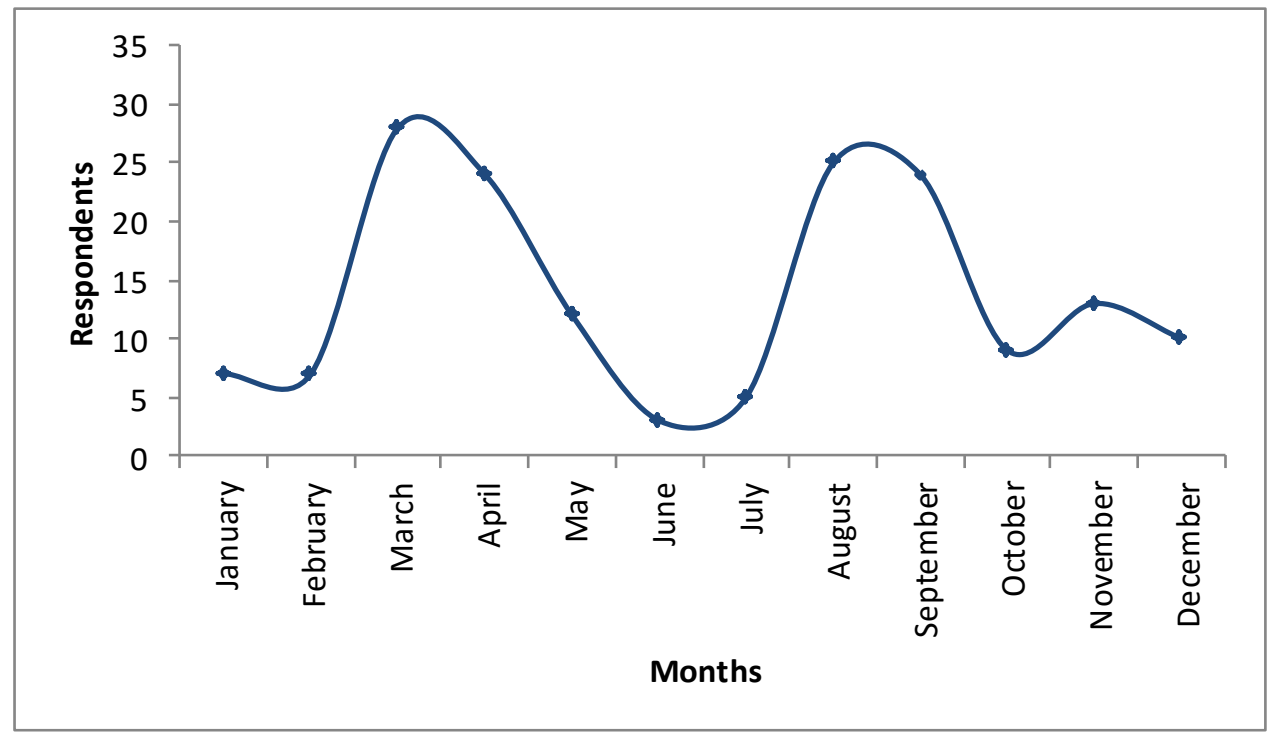

\section{Figure 2. Seasonality of using compost}

The main reason for this seasonality is the two-season cultivation of paddy in the area: Yala and Maha. During Febraury -March and July-August, the compost usage increases at an increasing rate and peaks in the months of March and August/September. Other cultivation crops can use compost in any month of the year or can use more than one month per year. Therefore, the other crops have no greater contribution to the compost demand in Yala and Maha season. But some of them can contribute to the impact of seasonality in Yala and Maha.

\section{The Demand for Compost}

As indicated in the methodology section, the demand was estimated using a Multiple Linear Regression of compost usage with land extent, sand content, price, cultivation type, and other fertilizer cost. The estimated regression coefficients were used in calculating demand elasticities with respect to the independent variables in the model (Table 2).

The results showed that income have a significant impact on demand at $5 \%$. Calculated elasticity value for income is 0.536 indicates that a rise in income by $10 \%$ would lead to an increase in demand for compost by $5.36 \%$.

The land extent of the crops that are cultivated using compost was also positive significant $5 \%$. Calculated elasticity value is 0.271 denotes that a $10 \%$ increase in land extent would lead to an increase in $2.7 \%$ of compost usage. Therefore, the demand is affected by the land extent, which is cultivated. Therefore, the use of compost needs to be improved by proper marketing propaganda. The present Government policy on promoting usage of natural fertilizers such as compost as 
against chemical fertilizer may lead to increase in the quantity demand because more land is allocated compost usage due to such propaganda.

Table 2. Estimation results from the Multiple Linear Regression

\begin{tabular}{lrrr}
\hline Variable & Coefficient & P value & Elasticity \\
\hline Income & 0.005 & 0.000 & 0.536 \\
Land Extent & 22.470 & 0.001 & 0.271 \\
Sand Content & -1.054 & 0.092 & -0.429 \\
Price & -1.638 & 0.033 & -0.311 \\
Paddy & 42.183 & 0.000 & 0.241 \\
Price of other fertilizer & 0.011 & 0.481 & 0.012 \\
Constant & 36.888 & 0.050 & \\
$\mathrm{~N}=100$ & & & \\
$\mathrm{R}^{2}=65.9 \%$ & & & \\
\hline
\end{tabular}

Note: I-Income, LE-Land Extent, SC-Sand Content, P-Price, Pa-Paddy=1, OFC-Other Fertilizer Cost

The sand content of the compost is significant at $10 \%$. The sand content elasticity is negative which means if sand content increases by $10 \%$ demand get decreases by $4.29 \%$ when all other independent variables are kept constant. Sand percentage denotes quality of compost. Higher the sand percentage, lower the quality. Quality is a very important parameter when in compost demand (Pandyaswargo and Premakumar, 2014). According to literature, the maximum sand percentage that should be in compost is $10 \%$ (Wijewardana, 2011). Most MSW compost including those produced at Sundarapola plant have higher sand percentage. Apart from sand percentage, farmers indicated that a product with proper packaging not contaminated with pathogens, properly treated and free from metals would be preferred.

The price of the compost is also significant at 5\% error level, with an elasticity value of 0.311 indicating that, if the price increases by $10 \%$, demand will decrease by $3.11 \%$. Thus, pricing strategy play a key role in selling compost. In order to induce farmers to use compost in their agricultural activities, the Government may subsidize usage making the prices to go down. This is a viable option given the present heavy subsidies provided to chemical fertilizer. Such a subsidy will not only help farmers in applying fertilizer but also reduce the burden of waste disposal by a significant manner. Other fertilizers are competitive products for compost. Increasing of other fertilizer cost must increase the demand for compost because these are substitutes. This is evident by the positive sign obtained for this variable though, it is not significant. Therefore, the provision of subsidies to natural fertilizers such as compost will reduce unnecessary use of chemical fertilizers, which is a major health hazard now in Sri Lanka. 
The significant coefficient in paddy cultivation indicates that compared to other crops, paddy uses $42 \mathrm{~kg}$ more of compost on the average. This is a very interesting and an important finding because paddy is one of the major crops that uses chemical fertilizers. Promotion of usage of compost in paddy cultivation will reduce the burden on subsidies for chemical fertilizers and will reduce health hazards such as kidney diseases, now common in Sri Lanka.

\section{Negative Aspects of Compost}

Although, $53 \%$ of the interviewed farmers had no issue with compost usage, $47 \%$ disagreed. Because this is close to half the sample, the problems they encounter must not be ignored if one is pursuing the advent of a compost culture in agricultural production.

Figure 3 summarizes the problems stated by farmers. Accordingly, the major critical attribute of compost is its inability to produce quick results in comparison to chemical fertilizer. Compost needs to be applied for a longer duration in larger quantities. According to them although, compost is applied, nutrient deficiency symptoms would not fade away. However, it can be easily managed with chemical fertilizer. In addition, there is a fear that improperly produced compost may cause infection for the entire cultivation. Some complain that damping off occur when using compost leading to crop losses and in turn economic losses for the farmers (Figure 3).

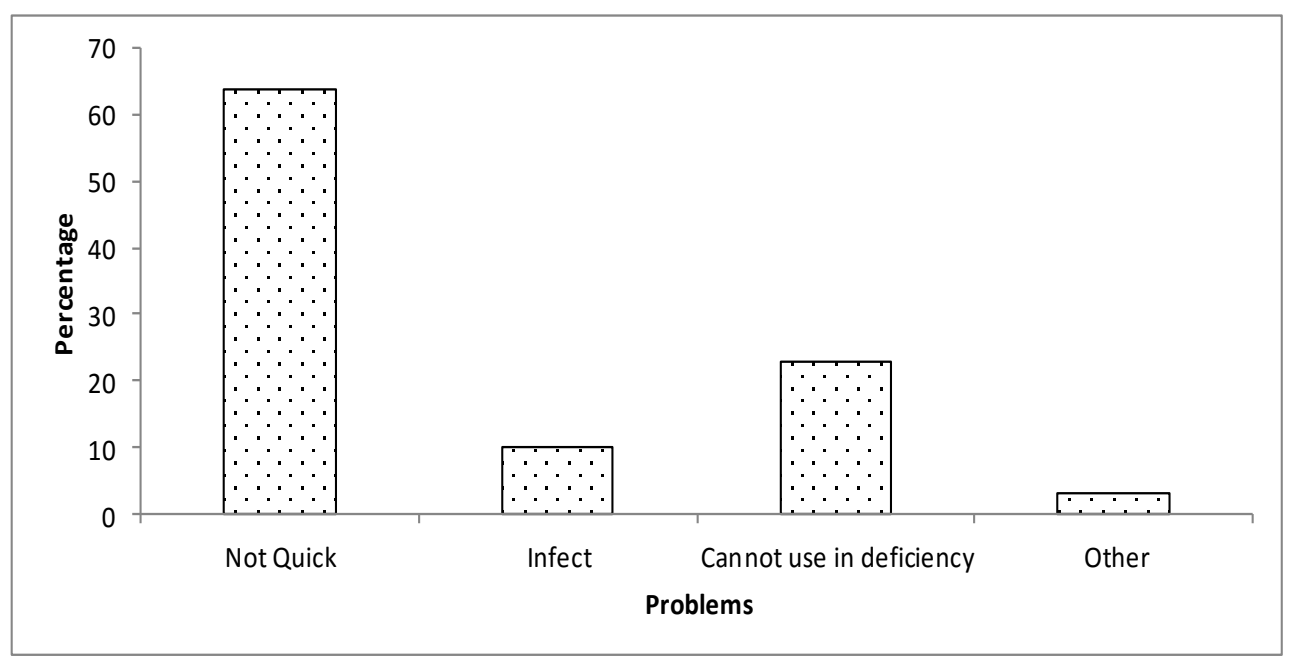

Figure 3. Negative aspects of compost indicated by the farmers 


\section{Conclusions}

When obtaining compost, farmers were concerned mainly about quality followed by price. So quality and price can play a major role when increasing or decreasing of a demand for compost. Farmers with large extents and higher income would demand more compost. With respect to the farmers that cultivate other crops, paddy farmers have significant effect for compost demand. In addition, the usage of compost differ with the type of cultivation and time of cultivation. Therefore, to precipitate farmers in to compost usage a proper strategy is in order. The product and pricing strategy are at the forefront. Because compost quality is highly respected in making purchasing decisions, this aspect needs to be addressed in production. In addition, free from contamination, metals and supplying in proper packaging in right sizes is also important. Therefore, such product strategies has to be clearly addressed. The pricing strategy may involve the Government because reduced prices increase usage.

This knowledge can be used to generate suitable subsidy policies which has three benefits from three sides. One from the reduced use of chemical fertilizers which reduces chemical induced diseases such as CKDU, conserving valuable foreign exchange used in importing expensive chemical fertilizers and reduction of subsidies that has to be given to chemical fertilizers which is substantial because of expensive nature of such fertilizers. There is also place strategy at play, especially in the form of time of usage. Because usage clearly varies over time, making compost available in large quantities at right time is important. Promotion of course is important given the nature of current low usage because of famer perceptions on negative aspects of compost.

\section{Acknowledgements}

Authors wish to express their gratitude to all the respondents for their valuable corporation and support rendered in carrying out this research successfully.

\section{References}

Ahmed, N., and C. Zurbrugg (2002). "Urban organic waste management in Karachi, Pakistan". 28 ${ }^{\text {th }}$ WEDC Conference in Kolkata, 18-22 November.

Alzaydi, A., S. Alsolaini and M. Ramadan (2013). "Demand, practices and properties of compost in the Western region of Kingdom of Saudi Arabia". Australian Journal of basic and Applied Sciences, 7(7): 768-776.

Burntley, S. J. (2007). "A review of municipal solid waste composition in the United Kingdom". Journal of Waste Management, 27(10): 1274-1285.

Cole, M. A., X. Liu and L. Zhang. L. (1995). "Effect of compost addition on pesticide degradation in planted soils". In: Bioremediation of recalcitrant organics. 
Folefack, A. J. J. and J. F. Adamowski (2012). "Application of the von Thunen Model in determining optimal locations to transport compost for crop production outside of Yaounde, Cameroon", Journal of Human Ecology, 39(2): 125-143.

Guerrero, L.A., G. Maas W. Hogland (2013). "Solid waste management challenges for cities in developing countries". Waste Management, 33: 220- 232.

Hasan, M. R., k. Tetsuo S. A. Islam (2009). "Landfill demand and allocation for municipal solid waste disposal in Dhaka city". Journal of Civil Engineering, 37(2): 133-149.

Palatnik, R., O. Ayalon and M. Shechter (2005). "Profile household demand for waste recycling services", Natural Resource and Environmental Research Center, University of Haifa, 31905, Israel.

Pandyaswargo, A. H. and D. G. T. Premakumara (2014). "Financial sustainability of modern composting: the economically optimal scale for municipal waste composting plant in developing Asia". International journal of Recycle Organic Waste in Agriculture, 3: 66.

Rouse, J., S. Rothenberger and Zurbrugg (2008). "Marketing Compost - A Guide for Compost Producers in Low and Middle Income Countries". Department of Water and Sanitation in Developing Countries.

Sharholy, M., K. Ahmad, G. Mahmood and R. C. Trivedi (2008). "Municipal solid waste management in Indian cities: a review". Journal of Waste Management, 28: 459-467.

Walpola, R. (2016). "Stinking to high heaven". Available from: http://www.ceylontoday.lk/90-114005 news-detail-stinking-to-high heaven.html (Assessed: 26 April 2016).

Wijewardana, H. (2011). "Standards of compost" (Brochure), Compost Production, Department of Agriculture, Sri Lanka. 